Carbohydrate Research, 104 (1982) 221-233

Elsevier Scientific Publishing Company, Amsterdam - Printed in The Netherlands

SYNTHESIS OF 6-O-(5-ACETAMIDO-3,5-DIDEOXY- $\alpha-D-g l y c e r o-D-g a l a c t o-2-$ NONULOPYRANOSYLONIC ACID)-D-GALACTOSE [6-O-( $N$-ACETYL- $\alpha$-DNEURAMINYL)-D-GALACTOSE]

Dominicus J. M. van der Vleugei, Fred R. Wassenburg, Jan W. Zwikker, and Johanies F. G. VLIEGENTHART ${ }^{*}$

Department of Bio-Organic Chemistry, State University of Utrecht, Utrecht (The Netherlands)

(Received August 24th, 1981; accepted for publication, November 6th, 1981)

ABSTRACT

Condensation of methyl 5-acetamido-4,7,8,9-tetra- $O$-acetyl-2-chloro-2,3,5trideoxy- $\beta$-D-glycero-D-galacto-2-nonulopyranosonate with benzyl 2,3,4-tri-O-benzyl$\beta$-D-galactopyranoside, using silver salicylate as promoter, gave benzyl 2,3,4-tri- $O$ benzyl-6-O-(methyl 5-acetamido-4,7,8,9-tetra- $O$-acetyl-3,5-dideoxy- $\alpha$-D-glycero-D-galacto-2-nonulopyranosylonate)- $\beta$-D-galactopyranoside (11) as the main product in $65 \%$ yield. Furthermore, the following by-products were formed: methyl 5-acetamido4,7,8,9-tetra- $O$-acetyl-3,5-dideoxy-2- $O$-salicyloyl-D-glycero-D-galacto-2-nonulopyranosonate, methyl 5-acetamido-4,7,8,9-tetra- $O$-acetyl-2,6-anhydro-3,5-dideoxy-D-glycero-D-galacto-non-2-enopyranosonate, and an impure compound that gave, after $O$-deacetylation and catalytic hydrogenolysis, 6-O-(methyl 5-acetamido-3,5-dideoxy$\beta$-D-glycero-D-galacto-2-nonulopyranosylonate)-D-galactose. $O$-Deacetylation of 11 gave benzyl 2,3,4-tri- $O$-benzyl-6-O-(methyl 5-acetamido-3,5-dideoxy- $\alpha$-D-glycero-Dgalacto-2-nonulopyranosylonate)- $\beta$-D-galactopyranoside, which was converted into 6-O-(methyl 5-acetamido-3,5-dideoxy- $\alpha$-D-glycero-D-galacto-2-nonulopyranosylonate)-D-galactose (13) by catalytic hydrogenolysis. Saponification of 13 gave the title compound as its potassium salt.

INTRODUCTION

$N$-Acetyl-D-neuraminic acid (Neu5Ac), which is the most common of the sialic acids, plays a role in several biological processes, in particular when located at the non-reducing ends of the carbohydrate chains of gangliosides and glycoproteins $^{1-4}$. It has been found that Neu5Ac can be linked to various positions of D-galactose $\mathrm{e}^{2-5}$, 2-acetamido-2-deoxy-D-galactose ${ }^{3,6,7}$, 2-acetamido-2-deoxy-D-glu$\cos e^{3,6,8}$, and sialic acid ${ }^{3.4}$. In all cases investigated so far, only $\alpha$-glycosidic linkages are involved, which are equatorial in the observed ${ }^{2} C_{5}(D)$ conformation of the Neu5Ac ring 9,10 .

*To whom correspondence should be addressed.

0008-6215/82/0000-0000/\$ 02.75, (C) 1982 - Elsevier Scientific Publishing Company 
In view of the biological significance of carbohydrate chains containing sialic acids, the chemical synthesis of such structures is important, because it provides pure compounds for structural and biochemical investigations. Our initial concern has been to develop convenient methods for the synthesis of sialodisaccharides with Neu5Ac in non-reducing positions. The synthesis of sialodisaccharides is complicated by the steric effects associated with the ketose character of Neu5Ac and the extreme lability of activated Neu5Ac derivatives towards elimination under current glycosylation conditions.

Some reports on the synthesis of this type of saccharide have appeared. Starting from methyl 5-acetamido-4,7,8,9-tetra- $O$-acetyl-2-chloro-2,3,5-trideoxy- $\beta$-D-glyceroD-galacto-2-nonulopyranosenate (5) and partially protected derivatives of D-glucose, D-galactose, and 2-acetamido-2-deoxy-D-glucose, a number of $(2 \rightarrow 6)-\alpha$ - and $(2 \rightarrow 3)-\alpha$ linked sialodisaccharides have been synthesised ${ }^{11}$ under silver carbonate-promoted, Koenigs-Knorr conditions in moderate yields $(8-18 \%)$. Similarly, condensation of methyl 4,5,7,8-tetra- $O$-acetyl-2-chloro-2,3-dideoxy- $\alpha$-D-manno-2-octulopyranosonate, for which the structural situation around the anomeric centre is comparable to that of 5 , with methyl 2,3-di- $O$-acetyl-p-D-ribofuranoside gave a low yield of methyl 2,3di-O-acetyl-5- $O$-(methyl 4,5,7,8-tetra- $O$-acetyl-3-deoxy- $\beta$-D-manno-2-octulopyranosylonate)- $\beta$-D-ribofuranoside ${ }^{12}$. Condensation of 5 or its free acid 4 with partially protected derivatives of Neu5Ac, D-galactose, and D-glucose, $i$ in the presence of a polymer-bound silver salt instead of silver carbonate, afforded ${ }^{13}$ sialodisaccharides in yields of $10-40 \%$.

Recentiy, we have shown that, by use of silver salicylate, 5 can be effectively converted into alkyl $x$-glycosides of Neu5Ac methyl ester ${ }^{14}$. We now report on the applicability of this approach to the synthesis of 6-O- $(N$-acetyl- $\alpha$-D-neuraminyl $)-\mathrm{D}-$ galactose (14).

RESLETSS AND DISCUSSION

For the synthesis of disaccharide 14, benzyl 2,3,4-tri- $O$-benzyl- $\beta$-D-galacto-
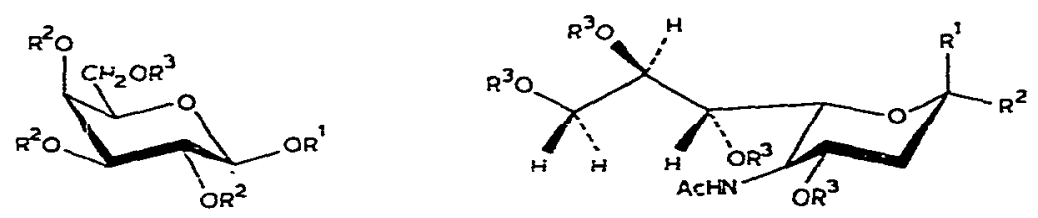

I R $R^{2}=B Z 1, R^{2}=R^{3}=H$

$2 R^{T}=R^{2}=821 \cdot R^{3}=H$

$$
\begin{aligned}
& 3 R^{2} \cdot R^{2}=O A C \cdot C O_{2} M e: R^{3}=A C \\
& 4 R^{2}=C \cdot R^{2}=C O_{2} H \cdot R^{3}=A C \\
& 5 R^{2}=C l \cdot R^{2}=C O_{2} M e \cdot R^{3}=A C \\
& 6 R^{2}=C O_{2} M e, R^{2}=O C H M e_{2} \cdot R^{3}=A C \\
& 7 R^{2} \cdot R^{2}=C O_{2} M e \cdot S a l: R^{3}=A C \\
& O R^{3}=C O_{2} M e \cdot R^{2}=O M e \cdot R^{3}=H \\
& 9 R^{2}=O M E \cdot R^{2}=C O_{2} M e \cdot R^{3}=H \\
& \text { Sal }=\text { salicyloyl }
\end{aligned}
$$


TABLE I

CARBON-13 CHEMICAL SHIFTS $(\delta)^{a}$ OF 2,6 , AND 11

\begin{tabular}{|c|c|c|c|}
\hline Carbon & 2 & 11 & $6^{c}$ \\
\hline \multicolumn{4}{|l|}{ NeuSAc residue } \\
\hline$C=O(C-1, N A c, O A C)$ & & $\begin{array}{l}170.7,170.4,170.1, \\
169.9,169.7,167.8\end{array}$ & $\begin{array}{l}170.7,170.4,170.0 \\
169.9,169.9,168.7\end{array}$ \\
\hline$c-2$ & & 98.6 & 98.5 \\
\hline$C-3$ & & 37.7 & 38.2 \\
\hline$C-4$ & & $67.3^{b}$ & $67.2^{b}$ \\
\hline$C-5$ & & 49.2 & 49.0 \\
\hline$c-6$ & & $72.6^{b}$ & $72.3^{\circ}$ \\
\hline$c-7$ & & $68.9^{b}$ & $68.8^{b}$ \\
\hline$C-8$ & & $68.9^{b}$ & $68.3^{b}$ \\
\hline$C-9$ & & 62.2 & 62.2 \\
\hline $\mathrm{CH}_{3}\left(\mathrm{CO}_{2} \mathrm{Me}\right)$ & & 52.6 & 52.2 \\
\hline $\mathrm{CH}_{3}$ (NAc) & & 23.0 & 22.8 \\
\hline $\mathrm{CH}_{3}(\mathrm{OAc})$ & & $20.9,20.6(3 x)$ & $20.8,20.5(3 x)$ \\
\hline \multicolumn{4}{|l|}{ Galactopyranoside residue } \\
\hline$C-1$ & 102.7 & 102.5 & \\
\hline$C-2$ & 79.3 & 79.3 & \\
\hline$C-3$ & 82.0 & 82.0 & \\
\hline$C-4$ & 70.8 & 70.6 & \\
\hline$c-5$ & 72.9 & 72.8 & \\
\hline C-6 & 61.6 & 62.6 & \\
\hline $\mathrm{Ph}-\mathrm{CH}_{2}$ & $74.9,74.4$ & $75.0,74.2$ & \\
\hline & $74.0,72.9$ & $73.3,72.6$ & \\
\hline
\end{tabular}

${ }^{a}$ Assignments were made with the aid of refs. 20, 21, 34-38, and additive increment rules (refs. 39-41). bAssignments may be interchanged. CTaken from ref. 14 .

pyranoside (2) and the glycosyl chloride ${ }^{15} 5$ were chosen as synthons. The "aglycon" 2 was selected, because benzyl groups are stable in the glycosylation step and can easily be removed by catalytic hydrogenolysis under mild conditions without rupture of the glycosidic linkage. Compound 2 was prepared from benzyl $\beta$-D-galactopyranoside $^{16}(1)$ in $66 \%$ yicld as described carlier ${ }^{17}$, using a modified detritylation procedure $^{18}$.

Condensation of $\mathbf{5}$ and $\mathbf{2}$ in benzene in the presence of silver salicylate gave a mixture of five components (t.l.c.). The formation of the side-products methyl 5acetamido-4,7,8,9-tetra- $O$-acetyl-3,5-dideoxy-2- $O$-salicyloyl-D-glycero-D-galacto-2-nonulopyranosonate (7) and methyl 5-acetamido-4,7,8,9-tetra- $O$-acetyl-2,6-anhydro3,5-dideoxy-D-glycero-D-galacto-non-2-enopyranosonate (10) could be largely suppressed by the presence of high concentrations of 2 , and therefore benzene solutions saturated with 2 were used. After work-up, the reaction mixture was fractionated by column chromatography on silica gel $60 \mathrm{H}$. The main product was the fully blocked disaccharide 11, which was obtained in $65 \%$ yield. ${ }^{13} \mathrm{C}-\mathrm{N} . \mathrm{m} . \mathrm{r}$. and $360-\mathrm{MHz}$, ${ }^{1} \mathrm{H}-$ 


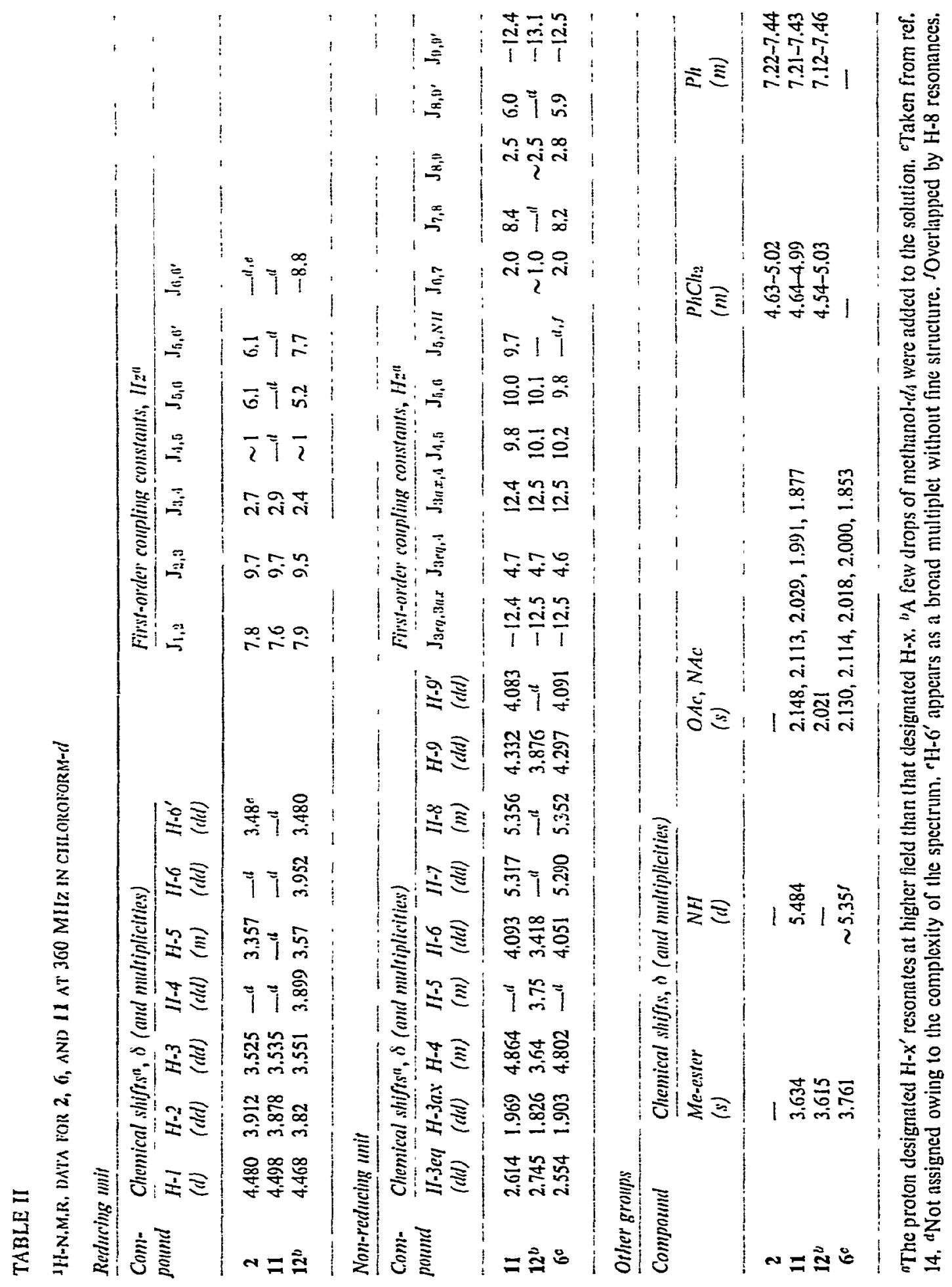


n.m.r. spectral data for $\mathbf{1 1}$ are presented in Tables I and II, respectively. For comparison, the data for 2 and methyl (isopropyl 5-acetamido-4,7,8,9-tetra- $O$-acetyl-3,5dideoxy- $x$-D-glycero-D-galacto-2-nonulopyranosid)onate ${ }^{14}$ (6) are included. The anomeric purity of 11 was demonstrated by the presence of only one double-doublet $(\delta 2.614)$ characteristic for $\mathrm{H}-3 e q$ of the sialic acid moiety ${ }^{14,19}$ in the region between $\delta 2$ and 3 of the ${ }^{1} H$-n.m.r. spectrum. This was further substantiated by the appearance of only two resonances $(\delta 102.5$, galactose $\mathrm{C}-1: \delta 98.2$, Neu5Ac C-2) in the anomeric region of the ${ }^{13} \mathrm{C}$-n.m.r. spectrum. Comparison of the resonance positions of the galactose $\mathrm{C}-6$ in the ${ }^{13} \mathrm{C}$-n.m.r. spectra of 2 and 11 showed that sialylation of position 6 of 2 is attended by a 1.0 p.p.m. downfield shift for C-6. This value is smaller than the usually observed sialylation shifts (2-3 p.p.m. downfield) for unblocked sialooligosaccharides ${ }^{20-22}$. Owing to the lack of ${ }^{1} \mathrm{H}$-n.m.r. reference data for solutions in chloroform- $d$, the anomeric configuration of the interglycosidic linkage of $\mathbf{1 1}$ cannot easily be derived at this stage.

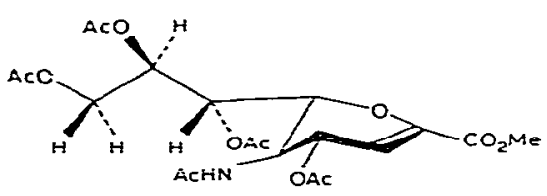

10

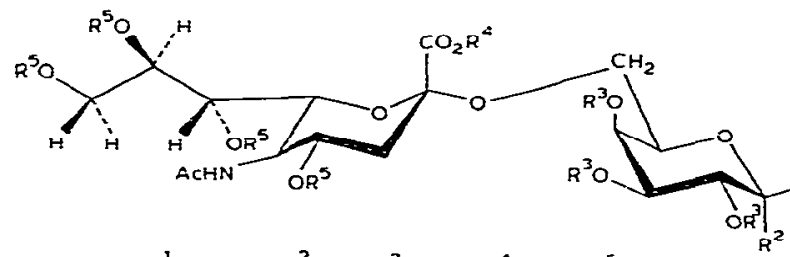

$$
\begin{aligned}
& 11 R^{\prime}=O B z 1, R^{2}=H, R^{3}=321, R^{4}=M e, R^{5}=A C \\
& 12 R^{1}=\text { OBzl, } R^{2}=R^{5}=H, R^{3}=B 2 l \cdot R^{4}=M e \\
& 13 R^{9}, R^{2}=H, O H ; R^{3}=R^{5}=H, R^{4}=M e \\
& 130 R^{\prime}, R^{2}=H \text {. OSiMe } ; R^{3}=R^{5}=S_{1} M e_{3} \cdot R^{4}=M e \\
& 14 R^{3}, R^{2}=H, O H: R^{3}=R^{5}=H ; R^{4}=K
\end{aligned}
$$

$O$-Deacetylation of 11 afforded crystalline 12 in $85 \%$ yield. The ${ }^{13} \mathrm{C}-$ n.m.r. and $360-\mathrm{MHz},{ }^{1} \mathrm{H}$-n.m.r. data are summarised in the Experimental and Table II, respectively. The benzyl groups were removed from 12 by palladium-catalysed hydrogenolysis in methanol, to give amorphous 13 in almost quantitative yield. The presence of an $\alpha$-glycosidic linkage in 13 was indicated by the $360-\mathrm{MHz},{ }^{1} \mathrm{H}$-n.m.r. spectrum $\left(\mathrm{D}_{2} \mathrm{O}\right)$ which showed signals for $\mathrm{H}-3 e q$ and $\mathrm{H}-4$ of Neu5Ac at $\delta 2.708$ and 3.77, respectively (ranges for $\alpha$-linked Neu5Ac derivatives ${ }^{23}: \mathrm{H}-3 e q, \delta$ 2.6-2.8; $\mathrm{H}-4, \delta 3.6-3.8$ ). The galactose moiety of 13 occurs almost exclusively in the pyranoid form ( $\mathrm{H}-1 \alpha: J_{1,2} 3.6 \mathrm{~Hz} ; \mathrm{H}-1 \beta: J_{1,2} 7.9 \mathrm{~Hz} ; \alpha \beta$-ratio, $\left.3: 7\right)$. The effect of anomerisation of the galactose residue is also expressed in the doubling of the resonance signal of the Neu5Ac H-3ax ( 0.007 p.p.m.) without influencing the signal of H-3eq (see also ref. 24). Further structural evidence for 13 was obtained by mass spectrometry of its per- $O$-trimethylsilyl $\left(\mathrm{Me}_{3} \mathrm{Si}\right)$ derivative 13a. Some significant fragment ions are presented in Table III. The intense peak at $m / z$ 726, which is the analogue of the peak at $\mathrm{m} / \mathrm{z} 583$ in $\mathrm{Me}_{3} \mathrm{Si}$-aldohexosyl-( $(\rightarrow 6)$-aldohexoses ${ }^{25}$, demonstrates the presence of the $(2 \rightarrow 6)$-linkage in 13.

After saponification of 13 with aqueous potassium hydroxide, the title product 
TABLE III

INTERPRETATION OF SOME IMPORTANT FRAGMENT IONS PRESENT IN THE MLASS SPECTRA OF THE Me3Si DERIVATIVES OF THE METHYL ESTERS OF 6- $O$-( $N$-ACETYL- $x$-D-NEURAMINYL)-D-GALACTOSE (13a) AND ITS $\beta$ ANOMER (15a)

\begin{tabular}{|c|c|c|c|}
\hline \multirow[t]{2}{*}{$\mathbf{m} / \mathbf{z}$} & \multirow[t]{2}{*}{ Eragment ${ }^{a}$} & \multicolumn{2}{|c|}{ Intensities ${ }^{b}$} \\
\hline & & $13 \mathbf{a}$ & $15 \mathbf{a}$ \\
\hline 1061 & $\mathbf{M}$ & 0.8 & 0.7 \\
\hline 1046 & $\mathrm{M}-\mathrm{CH}_{3}$ & 2.9 & 7.8 \\
\hline 1002 & $\mathrm{M}-\mathrm{COOCH}_{3}$ & 4.1 & 2.7 \\
\hline 856 & $\mathrm{M}-\mathrm{CH}\left(\mathrm{OSiMe}_{3}\right) \mathrm{CH}_{2} \mathrm{OSiMe}_{3}$ & 6.5 & 28.3 \\
\hline 726 & Neu5Ac-OCH ${ }_{2} \mathrm{CH}=\mathrm{OSiMe}_{3}$ & 15.2 & 12.8 \\
\hline 624 & Neu5AC-OSiMe $-\mathrm{COOCH}_{3}$ & 7.6 & 16.0 \\
\hline 594 & [Neu5Ac] & 4.2 & 8.3 \\
\hline 504 & $594-\mathrm{Mc}_{3} \mathrm{SiOH}$ & 9.0 & 29.8 \\
\hline 451 & [Gall] & 3.8 & 10.0 \\
\hline 361 & $451-\mathrm{Me}_{3} \mathrm{SiOH}$ & 3.5 & 5.5 \\
\hline 300 & $\begin{array}{l}\mathrm{AcNH}=\mathrm{CHC}\left(\mathrm{OSiMe}_{3}\right)=\mathrm{CHCH}=\mathrm{CHOSiMe}_{3} \\
\mathrm{ACNH}=\mathrm{CHCH}=\mathrm{C}\left(\mathrm{OSiMe}_{3}\right) \mathrm{CH}=\mathrm{CHOSiMe}\end{array}$ & 14.9 & 46.0 \\
\hline 298 & $\mathrm{M}-\mathrm{HO}-\mathrm{Gal}-\mathrm{CH}\left(\mathrm{OSiMe}_{3}\right) \mathrm{CH}_{2} \mathrm{OSiMe}_{3}-\mathrm{Me}_{3} \mathrm{SiOH}$ & 16.7 & 31.0 \\
\hline 217 & $\mathrm{Me}_{3} \mathrm{SiOCH}=\mathrm{CHCH}=\mathrm{OSiMe}$ & 75.3 & 38.1 \\
\hline 204 & $\mathrm{Me}_{3} \mathrm{SiO}=\mathrm{CHCHOSiMe}$ & 100.0 & 100.0 \\
\hline 186 & $\begin{array}{l}\text { AcNHCH }=\mathrm{CHCHOSiMe} \\
\mathrm{AcNH}=\mathrm{CHC}\left(\mathrm{OSiMe}_{3}\right)=\mathrm{CH}_{2} \\
\mathrm{NH}_{2}=\mathrm{CHCOCH} 2 \mathrm{CH}=\mathrm{CHOSiMe}_{3}\end{array}$ & 23.1 & 20.0 \\
\hline 173 & $\mathrm{ACNHCHCH}=\mathrm{OSiMe}_{3}$ & 4.6 & 5.3 \\
\hline
\end{tabular}

aFor a proper description of the fragment ions, the disaccharides 13a and $15 a$ are considered to be NeuSAc-O-Gal. 'The intensities of the ions are given relative tc that of $m / z 204$.

was obtained in $87 \%$ yield in the form of its stable potassium salt 14. As described for 13, the galactopyranose form of 14 is indicated by its $360-\mathrm{MHz}$, $\mathrm{H}$-n.m.r. spectrum (H-1 $\alpha: J_{1.2} 3.7 \mathrm{~Hz} ; \mathrm{H}-1 \beta: J_{1,2} 7.9 \mathrm{~Hz} ; \alpha \beta$-ratio, $\left.3: 7\right)$. Again, a doubling of the resonance signal of the Neu5Ac H-3ax ( 0.008 p.p.m.) was observed and no effect on the signal of $\mathrm{H}-3 e q$ was detectable. The resonance position of $\mathrm{H}-3 e q$ at $\delta 2.721$ and the fact that 14 was cleaved by Clostridium perfringens neuraminidase proved the $\alpha$ configuration of the glycosidic linkage in 14. Finally, the presence of the anticipated $(2 \rightarrow 6)$-linkage in 14 was confirmed via methylation analysis of borodeuteride-reduced 14.

As mentioned above, the condensation reaction gives rise to few side-products. Upon chromatography of the crude reaction mixture, two compounds were eluted from the column prior to 11. The fast-moving was excess of 2 , which could be easily recovered. An impure compound was eluted second, which, after $O$-deacetylation, purification by column chromatography, and catalytic hydrogenolysis, gave disaccharide 15 in $3 \%$ yield based on the precursor of 5, methyl 5-acetamido-2,4,7,8,9penta-O-acetyl-3,5-dideoxy-D-glycero-D-galacto-2-nonulopyranosonate (3). The pres- 
ence of a $\beta$-glycosidic linkage in 15 was indicated by the $360-\mathrm{MHz},{ }^{1} \mathrm{H}$-n.m.r. spectrum $\left(\mathrm{D}_{2} \mathrm{O}\right)$ which showed signals for $\mathrm{H}-3 e q$ and $\mathrm{H}-4$ of Neu5Ac at $\delta 2.453$ and 4.098, respectively (ranges for $\beta$-linked Neu5Ac derivatives ${ }^{23}: \mathrm{H}-3 e q, \delta 2.1-2.5 ; \mathrm{H}-4$, $\delta$ 3.9-4.2). As shown in Table IV, the difference in anomeric configuration of the glycosidic linkage in 13 and 15 is aiso reflected by the resonance positions of the Neu5Ac $\mathrm{H}-7$ and the protons of the $\mathrm{N}$-acetyl group. For comparison, the corresponding data for methyl (methyl 5-acetamido-3,5-dideoxy- $\alpha-{ }^{14}$ and - $\beta$-D-glycero-Dgalacto-2-nonulopyranosid)onate ${ }^{23}$ (8 and 9) are included. Although the absolute differences in the resonance positions are subtle, the data demonstrate the structural relationship of 15 and 9 on the one hand, and of 13 and 8 on the other. The statements regarding the pyranosid form of the galactose moiety of 13 also hold for 15 (H-1 $\alpha$ : $J_{1,2} 3.4 \mathrm{~Hz} ; \mathrm{H}-1 \beta: J_{1,2} 7.6 \mathrm{~Hz} ; \alpha \beta$-ratio, $\left.3: 7\right)$. The doubling of the resonance signal of $\mathrm{H}-3$ eq was small ( $\sim 0.001$ p.p.m.) but significant. In contrast to 13, no doubling of

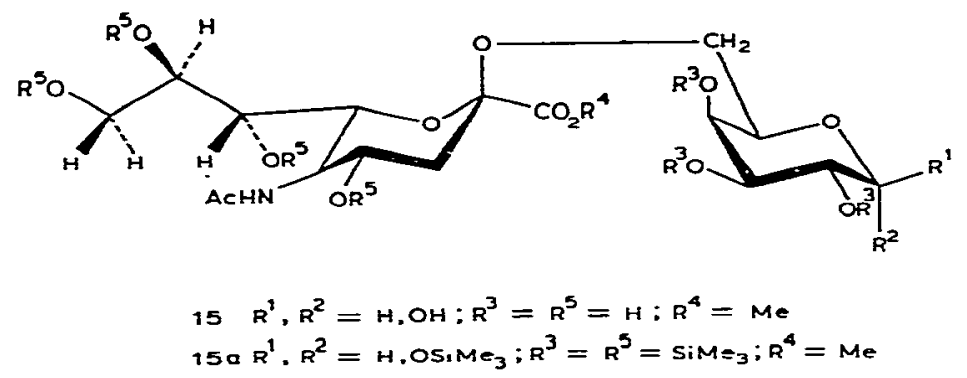

the resonance signal of $\mathbf{H}-3 a x$ was observed. Mass-spectral data of per- $O$-trimethylsilylated 15 (15a), showing, inter alia, the presence of a $(2 \rightarrow 6)$-linkage in 15, are summarised in Table III.

Two other by-products of the condensation reaction were eluted after 11 . The fast-moving component was identified as 7 by ${ }^{1}$ H-n.m.r. spectroscopy. Apart from resonances of the Neu5Ac moiety, the spectrum showed the characteristic features of a saiicyloyl group. The formation of 7 proceeds from the direct reaction between 5 and silver salicylate ${ }^{26}$. The slow-moving compound was identified as 10 , which is

\section{TABLE IV}

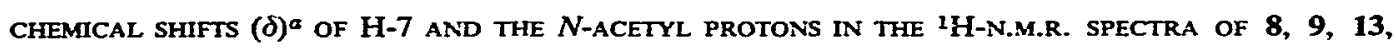
AND 15 AT $360 \mathrm{MHz}$

\begin{tabular}{lllll}
\hline & $9^{b}$ & 15 & $8^{c}$ & 13 \\
\hline NAc & 2.050 & 2.050 & 2.034 & 2.034 \\
H-7 & 3.581 & 3.586 & 3.559 & 3.547
\end{tabular}

$a_{\text {Measured in deuterium oxide. }}$ V Values obtained from ref. 23. cValues obtained from ref. 14. 
formed from 5 by elimination of $\mathrm{HCl}$. The $360-\mathrm{MHz},{ }^{1} \mathrm{H}-$ n.m.r. spectrum of 10 showed the absence of the resonance signals of $\mathrm{H}-3 e q$ and $\mathrm{H}-3 \mathrm{ax}$, and the appearance of a one-proton doublet at $\delta 5.987$ originating from the olefinic $\mathbf{H}-3$.

EXPERIMENTAL

Materials. - $N$-Acetyl-D-neuraminic acid (Neu5Ac) was isolated from the urine of a patient with sialuria ${ }^{27}$. Methyl 5-acetamido-2,4,7,8,9-penta- $O$-acetyl3,5-dideoxy-D-glycero-D-galacto-2-nonulopyranosonate (3) was prepared from Neu5Ac according to Kuhn et al. ${ }^{15}$. The product was crystallised from chloroformether; m.p. $154-155^{\circ},[x]_{\mathrm{D}}^{20}-4.6^{\circ}$ (c 1.2, chloroform); lit. ${ }^{15}$ m.p. $156-157^{\circ},[x]_{\mathrm{D}}^{20}$ $-3.3^{\circ}$ (c 1.0, chloroform).

General methods. - Melting points were determined with a Meopta meltingpoint microscope and are uncorrected. Evaporations were conducted in vacuo at $<40^{\circ}$ (bath). Elemental analyses were carried out at the Institute for Organic Chemistry TNO, Utrecht, The Netherlands. Specific rotations were measured with a Perkin-Elmer 241 polarimeter, using a 10-cm micro-cell. I.r. spectra ( $\mathrm{KBr}$ discs) were recorded with a Perkin-Elmer Model 457 spectrophotometer.

${ }^{1}$ II-N.m.r. spectra were recorded with a Varian EM-390 (90 MHz) spectrometer and a Bruker HX-360 (360 MHz) spectrometer, operating in the Fouriertransform mode, at probe temperatures of $25^{\circ}$. Chemical shifts $(\delta)$ for solutions in chloroform- $d$ are given relative to tetramethylsilane as internal standard. For solutions in deuterium oxide, sodium 4,4-dimethyl-4-silapentane-1-sulphonate was used (indirectly, acetone in deuterium oxide: $\delta$ 2.225). Prior to spectral analysis, solutions in deuterium oxide were exchanged three times with intermediate lyophilisation. ${ }^{13} \mathrm{C}-\mathrm{N}$.m.r. spectra were recorded at $\sim 30^{\circ}$ with a Varian CFT-20 spectrometer operating at $20 \mathrm{MHz}$ in the Fourier-transform mode with complete proton-decoupling. Chemical shifts $(\delta)$ are given relative to tetramethylsilane as internal standard for solutions in chloroform- $d$.

Trimethylsilylation of 1-mg samples of sugars was performed with hexamethyldisilazane and chlorotrimethylsilane in pyridine ${ }^{28}$. Sugar analysis by methanolysis, followed by g.l.c. of the trimethylsilylated methyl glycosides, was performed as indicated previously ${ }^{29,30}$.

G.l.c. was carried out on a Varian Aerograph 2740-30-01, equipped with a flame-ionisation detector. The injection-port and detector temperatures were $210^{\circ}$ and $230^{\circ}$, respectively. The nitrogen flow-rate was $35 \mathrm{~mL} / \mathrm{min}$. For partially methylated alditol acetates, a glass column $(1.60 \mathrm{~m} \times 4.0 \mathrm{~mm}$ i.d. $)$ packed with $3 \%$ of $\mathrm{OV}$ 225 on Chromosorb W HP (100-120 mesh) and an oven temperature of $180^{\circ}$ were used. A glass column $(2.00 \mathrm{~m} \times 4.0 \mathrm{~mm}$ i.d.) packed with $3.8 \%$ of SE-30 on Chromosorb W HP ( $80-100$ mesh) was used for the analysis of per- $O$-trimethylsilyl derivatives of sugars; the oven temperature was $290^{\circ}$ for disaccharide samples and was programmed from $135 \rightarrow 220^{\circ}$ at $1 \%$ min for monosaccharide methyl glycosides.

G.1.c.-m.s. was performed with a combined Hewlett-Packard 5710A gas 
chromatograph/Jeol JMS-D300 mass spectrometer/Jeol JMA-2000 mass data analysis system. 70-eV Mass spectra were recorded for an ion-source temperature of $225^{\circ}$, an accelerating voltage of $3 \mathrm{kV}$, and an ionising current of $300 \mu \mathrm{A}$. The same stationary phases were used as described above. 70-eV Mass spectra of disaccharide samples were recorded on a ZAB-2F VG Micromass mass spectrometer (ion-source temperature, $180^{\circ}$; probe temperature, $130-150^{\circ}$; accelerating voltage, $8 \mathrm{kV}$; ionising current, $100 \mu \mathrm{A})$.

T.l.c. was performed on silica gel (Schleicher and Schüll TLC Ready Plastic Foil FR-1500) and detection was effected with u.v. light or by spraying with $20 \%$ conc. sulphuric acid in methanol followed by charring at $130^{\circ}$ for $5-10 \mathrm{~min}$. The following solvents were used: $A$, chloroform-methanol $(25: 1)$; $B$, chloroformmethanol $(10: 1) ; C$, ethyl acetate-2-propanol-water $(2: 2: 1) ; D, 1$-propanol-water $(7: 3)$.

Incubations with Clostridium perfringens neuraminidase (EC 3.2.1.18) were performed at $37^{\circ}$ and $\mathrm{pH} 5.4(0.1 \mathrm{M} \mathrm{Na} / \mathrm{K}$ phosphate buffer) in a total volume of $0.1 \mathrm{~mL}$, containing $1.7 \mathrm{mU}$ of enzyme and $0.2 \mu \mathrm{mol}$ of substrate. Free sialic acid was determined by Warren's method ${ }^{31}$.

Benzyl 2,3,4-tri-O-benzyl- $\beta$-D-galactopyranoside (2). - Compound 2 was obtained from benzyl $\beta$-D-galactopyranoside ${ }^{16}(1 ; 15.8 \mathrm{~g}, 58.5 \mathrm{mmol})$ by tritylation and benzylation ${ }^{17}$, followed by detritylation ${ }^{18}$. The resulting syrup was chromatographed on a column of silica gel (Merck Kieselgel 60, 70-230 mesh) vith chloroform and crystallised from chloroform-hexane, to give $2(21.0 \mathrm{~g}, 66 \%)$, m.p. 94.5-95 $[\alpha]_{\mathrm{D}}^{20}-46^{\circ}$ (c 1, chloroform); lit. ${ }^{17}$ m.p. $96-96.5^{\circ},[\alpha]_{\mathrm{D}}^{20}-46.1^{\circ}(c 3.0$, chloroform); lit. ${ }^{32}$ m.p. $96^{\circ},[\alpha]_{\mathrm{D}}-49^{\circ}$ (c 1.3, chloroform); $v_{\max }^{\mathrm{KBr}} 3300$ (broad, $\left.\mathrm{OH}\right), 732$, and $695 \mathrm{~cm}^{-1}$ (Ph). For ${ }^{13} \mathrm{C}$ - and ${ }^{1} \mathrm{H}$-n.m.r. data, see Tables I and II, respectively.

Condensation of 2 and 5. - Compound 5, freshly prepared ${ }^{15}$ from $3(1.22 \mathrm{~g}$, $2.29 \mathrm{mmol})$, was dissolved in dry benzene $(14 \mathrm{~mL})$. After the addition of $2(9.20 \mathrm{~g}$, $17.06 \mathrm{mmol})$ and silver salicylate ${ }^{14}(1.10 \mathrm{~g}, 4.56 \mathrm{mmol})$, the mixture was stirred for $17 \mathrm{~h}$ at room temperature in the dark with exclusion of moisture. T.l.c. (solvent $A$ ) revealed five spots having $R_{F}$ values of $0.60,0.55,0.40,0.32$, and 0.27 . The mixture was diluted with chloroform and filtered through a bed of diatomaceous earth. The inorganic solids were washed extensively with chloroform. The combined filtrates and washings were evaporated in vacuo and the resulting syrupy residue was fractionated on a column $(37 \times 4 \mathrm{~cm})$ of silica gel (Mierck Kieselgel $60 \mathrm{H})$ equipped with an air pump for flow-rate regulation $(40 \mathrm{~mL} / \mathrm{h})$. The excess of $2\left(8.02 \mathrm{~g} ; R_{\mathrm{F}} 0.60\right.$, solvent $A$ ) was eluted with chloroform, and the other carbohydrate fractions were eluted with chloroform-methanol $(100: 1)$.

The first fraction $(161 \mathrm{mg})$ contained one main component $\left(R_{\mathrm{F}} 0.55\right.$, solvent $\left.A\right)$. After evaporation, the residue was dissolved in dry methanol $(20 \mathrm{~mL})$ containing a catalytic amount of potassium tert-butoxide. The solution was stirred at room temperature until t.l.c. (solvent $B$ ) revealed that the reaction was complete $(2-3 \mathrm{~h}$ ), deionised with Dowex 50W-X8 $\left(\mathrm{H}^{+}\right)$resin at $0^{\circ}$, and evaporated. The resulting syrup was chromatographed on a column $(16 \times 1.2 \mathrm{~cm})$ of silica gel (Merck Kieselgel 60, 
$70-230 \mathrm{mesh})$ with chloroform (20 mL) and then chloroform-methanol (25:1). The main product was obtained as a syrup $(61 \mathrm{mg})$ that was homogeneous in t.l.c. (solvents $B$ and $C$ ). It was dissolved in dry methanol $(10 \mathrm{~mL})$ and hydrogenoiysed over $\mathrm{Pd} / \mathrm{C}$ $(10 \%, 25 \mathrm{mg})$ until t.l.c. (solvent $C$ ) showed that the reaction was complete $(1.5 \mathrm{~h})$. The mixture was filtered and concentrated, and an aqueous solution of the residue was lyophilised, to give the amorphous, $\beta$-linked sialodisaccharide methyl ester 15 (35 mg. $3 \%$ based on 3 ). The product was homogeneous in t.l.c. (solvents $C$ and $D$ ), and had $[\alpha]_{D}^{20}-2.6^{\circ}$ ( $c 0.33$, methanol) and a Neu5Ac/galactose ratio of 1.00:1.02. The m.s. data of per- $O$-trimethylsilylated 15 (15a) are given in Table III. ${ }^{1} \mathrm{H}$-N.m.r. data (360 $\mathrm{MHz}_{2} \mathrm{D}_{2} \mathrm{O}$ ): NeuSAc unit: $\delta 1.788\left(\mathrm{dd}, 1 \mathrm{H}, J_{3 a x .3 e q}-12.5, J_{3 a x .4} 12.5 \mathrm{~Hz}\right.$, $\mathrm{H}-3 a x), 2.050$ (s, $3 \mathrm{H}, \mathrm{NAc}$ ), 2.452, 2.453 [2dd, $1 \mathrm{H}, J_{3 a x, 3 e q}-12.5, J_{3 e q, 4} \sim 4.7 \mathrm{~Hz}$, $\mathrm{H}-3 e q$ ( $x$ and $\beta$ anomer of galactopyranose)], 3.586 (dd, $1 \mathrm{H}, J_{6.7} \sim 1, J_{7.8} 9.7 \mathrm{~Hz}$, H-7), 3.664 (dd, $1 \mathrm{H}, J_{8.9} 6.1, J_{9,9^{*}}-13.1 \mathrm{~Hz}, \mathrm{H}-9^{\prime}$ ), 3.868 (s, $3 \mathrm{H}, \mathrm{CO}_{2} \mathrm{Me}$ ), 3.895 (dd, $\left.1 \mathrm{H}, J_{4.5} \sim 10 . J_{5,6} \sim 10 \mathrm{~Hz}, \mathrm{H}-5\right)$, and $4.098\left(\mathrm{~m}, 1 \mathrm{H}, J_{3 a x, 4} 12.5, J_{3 e q .4} \sim 4.7\right.$, $\left.J_{4.5} \sim 10 \mathrm{~Hz}, \mathrm{H}-4\right)$; galactopyranose unit: $\delta 3.474\left[\mathrm{dd}, 0.7 \mathrm{H}, J_{1,2} 7.6, J_{2.3} 9.4 \mathrm{~Hz}\right.$, H-2 ( $\beta$ anomer)], 4.182 [broad $\mathrm{m}, 0.3 \mathrm{H}, \mathrm{H}-5$ ( $\alpha$ anomer)], 4.570 (d, $0.7 \mathrm{H}, J_{1,2}$ $7.6 \mathrm{~Hz}, \mathrm{H}-1 \beta)$, and $5.253\left(\mathrm{~d}, 0.3 \mathrm{H}, J_{1.2} 3.4 \mathrm{~Hz}, \mathrm{H}-\mathrm{l} \alpha\right)$.

Anal. Calc. for $\mathrm{C}_{18} \mathrm{H}_{31} \mathrm{NO}_{14} \cdot \mathrm{H}_{2} \mathrm{O}: \mathrm{C}, 42.94 ; \mathrm{H}, 6.61 ; \mathrm{N}, 2.78$. Found: $\mathrm{C}$, 42.82: $\mathrm{H}, 6.40 ; \mathrm{N}, 2.85$.

The second fraction gave the protected, $x$-linked sialodisaccharide 11 (1.50 g, $65 \%$ based on 3$)$, which was homogeneous in t.l.c. $\left(R_{\mathrm{F}} 0.40\right.$, solvent $\left.A\right)$. A sample was crystallised from carbon tetrachloride; m.p. $79-80^{\circ},[\alpha]_{D}^{20}-5.0^{\circ}$ (c 1.7, methanol); $v_{\max }^{\mathrm{KBr}} 3380(\mathrm{NH}), 1770-1730$ (OAc, $\mathrm{CO}_{2} \mathrm{Me}$ ), 1665 (Amide I), 1545 (Amide II), 735, and $698 \mathrm{~cm}^{-1}$ (Ph). For ${ }^{13} \mathrm{C}$ - and ${ }^{1} \mathrm{H}$-n.m.r. data, see Tables I and II, respectively.

Anal. Calc. for $\mathrm{C}_{54} \mathrm{H}_{63} \mathrm{NO}_{18}: \mathrm{C}, 63.96 ; \mathrm{H}, 6.26 ; \mathrm{N}, 1.38$. Found: C, 63.69; $H, 6.31 ; \mathrm{N}, 1.36$.

For deblocking of 11, see below.

The third fraction $(44 \mathrm{mg})$ consisted mainly of the 2-O-salicyloyl derivative 7 $\left(R_{\mathrm{F}} 0.32\right.$, solvent $\left.A\right)$; ${ }^{1} \mathrm{H}$-n.m.r. data of $7(90 \mathrm{MHz}$, chloroform-d): Neu5Ac unit: $\delta 2.73\left(\mathrm{dd}, \mathrm{l} \mathrm{H}, J_{3 a x, 3 e q}-13.5, J_{3 e q, 4} 4.8 \mathrm{~Hz}, \mathrm{H}-3 e q\right), 3.82\left(\mathrm{~s}, 3 \mathrm{H}, \mathrm{CO}_{2} \mathrm{Me}\right.$ ), and $4.48\left(\mathrm{dd}, 1 \mathrm{H}, J_{8.9} \sim 2.9, J_{9,9^{\circ}}-12.9 \mathrm{~Hz}, \mathrm{H}-9\right.$ ); salicyloyl unit: $\delta 6.80-7.10(\mathrm{~m}, 2 \mathrm{H}$, $\mathrm{H}-3,5), 7.51\left(\mathrm{~m}, 1 \mathrm{H}, J_{\text {vic }} 9.0\right.$ and $7.5, J_{4,6} \sim 2 \mathrm{~Hz}, \mathrm{H}-4$ ), 7.86 (dd, $1 \mathrm{H}, J_{5.6} 7.5$, $\left.J_{4,6} \sim 2 \mathrm{~Hz}, \mathrm{H}-6\right)$, and $10.17(\mathrm{~s}, 1 \mathrm{H}, \mathrm{OH}$; intramolecularly bridged proton).

The fourth fraction was a mixture of mainly 7 and the unsaturated compound $10\left(R_{F} 0.32\right.$ and 0.27 , respectively; solvent $\left.A\right)$ as shown by t.l.c., and was not collected.

The fifth fraction ( $45 \mathrm{mg})$ contained mainly 10 as judged by t.l.c. $\left(R_{\mathrm{F}} 0.27\right.$, solvent $A$ ) and ${ }^{1}$ H-n.m.r. spectroscopy; ${ }^{1} \mathrm{H}$-n.m.r. data of 10 (360 MHz, chloroformd) $\delta 1.921,2.051,2.062,2.075,2.124(5 \mathrm{~s}, 15 \mathrm{H}, \mathrm{NAc}$ and $4 \mathrm{OAc}), 3.799(\mathrm{~s}, 3 \mathrm{H}$, $\mathrm{CO}_{2} \mathrm{Me}$ ), 4.197 (dd, $1 \mathrm{H}, J_{8,9} \cdot 6.7, J_{9,9^{\circ}}-12.5 \mathrm{~Hz}, \mathrm{H}-9^{\prime}$ ), 4.654 (dd, $1 \mathrm{H}, J_{8,9} \sim 3.3$, $\left.J_{9,9},-12.5 \mathrm{~Hz}, \mathrm{H}-9\right), 5.987\left(\mathrm{~d}, 1 \mathrm{H}, J_{3,4} 2.7 \mathrm{~Hz}, \mathrm{H}-3\right.$ ), and $6.086\left(\mathrm{~d}, 1 \mathrm{H}, J_{5, \mathrm{NH}} 9.7\right.$ $\mathrm{Hz}, \mathrm{NH}$ ).

Benzyl 2,3,4-tri-O-benzyl-6-O-(methyl 5-acetamido-3,5-dideoxy- $\alpha$-D-glyceroD-galacto-2-nonulopyranosylonate)- $\beta$-D-galactopyranoside (12). - A solution of 11 
$(1.38 \mathrm{~g}, 1.36 \mathrm{mmol})$ in dry methanol $(40 \mathrm{~mL})$ containing a catalytic amount of potassium tert-butoxide was stirred at room temperature until t.l.c. (solvent $B$ ) showed that $O$-deacetylation was complete $(5 \mathrm{~h})$. After treatment with Dowex $50 \mathrm{~W}-\mathrm{X} 8\left(\mathrm{H}^{*}\right)$ resin at $0^{\circ}$, and evaporation, the slowly crystallising residue was recrystallised from carbon tetrachloride, to give 12 (981 mg, $85 \%$ ), m.p. 183-184 ${ }^{\circ}$, $[\alpha]_{\mathrm{D}}^{20}-1.3^{\circ}$ (c 0.95, methanol); $v_{\max }^{\mathrm{KBr}} 3570,3510,3350(\mathrm{OH}, \mathrm{NH}), 1750\left(\mathrm{CO}_{2} \mathrm{Me}\right)$, 1635 (Amide I), 1590 (Amide II), 750, 736, and $700 \mathrm{~cm}^{-1}(\mathrm{Ph}) ;{ }^{13} \mathrm{C}$-n.m.r. data (20 MHz, chloroform-d): Neu5Ac unit: $\delta 173.9$ (carbonyl, NAc), 169.3 (C-1), 98.5 (C-2), $53.2(\mathrm{C}-5), 52.9\left(\mathrm{CH}_{3}\right.$, ester), $40.2(\mathrm{C}-3)$, and $22.8\left(\mathrm{CH}_{3}, \mathrm{NAc}\right)$; galactopyranuside unit: $\delta$ 102.8 (C-1), 81.9 (C-3), and 79.3 (C-2); 'H-H.m.r. data: Table II. Anal. Calc. for $\mathrm{C}_{46} \mathrm{H}_{55} \mathrm{NO}_{14}: \mathrm{C}, 65.31 ; \mathrm{H}, 6.55 ; \mathrm{N}, 1.66$. Found: $\mathrm{C}, 64.99$ : $\mathrm{H}, 6.45 ; \mathrm{N}, 1.66$.

6-O-(Metiyl 5-acetamido-3,5-dideoxy- $\alpha$-D-glycero-D-galacto-2-nonulopyranosy:lonate)-D-galactose (13). - A solution of $12(550 \mathrm{mg}, 0.65 \mathrm{mmol})$ in dry methanol $(80 \mathrm{~mL})$ was hydrogenolysed over $\mathrm{Pd} / \mathrm{C}(10 \%, 230 \mathrm{mg})$ until t.l.c. (solvent $C$ ) showed that the reaction was complete $(1 \mathrm{~h})$. The mixture was filtered, concentrated, and finally lyophilised as an aqueous solution, to give amorphous $13(326 \mathrm{mg}, 99 \%)$. The product was homogeneous in t.l.c. (solvent $E$ ), and had $[\alpha]_{D}^{20}+5.4^{\circ}(c 0.8$, methanol); ${ }^{1} \mathrm{H}$-n.m.r. data ( $360 \mathrm{MHz}, \mathrm{D}_{2} \mathrm{O}$ ): Neu5Ac unit: $\delta 1.833,1.840[2 \mathrm{dd}, 1 \mathrm{H}$, $J_{3 a x, 3 e q}-12.4, J_{3 a x, 4} 12.4 \mathrm{~Hz}, \mathrm{H}-3 a x$ ( $\alpha$ and $\beta$ anomer of galactopyranose)], 2.034 (s, $3 \mathrm{H}, \mathrm{NAc}$ ), 2.708 (dd, $1 \mathrm{H}, J_{3 a x, 3 e q}-12.4, J_{3 e q, 4} 4.6 \mathrm{~Hz}, \mathrm{H}-3 e q$ ), 3.547 (dd, $1 \mathrm{H}$, $\left.J_{6,7} \sim 1, J_{7,8} 8.7 \mathrm{~Hz}, \mathrm{H}-7\right), 3.77(\mathrm{~m}, 1 \mathrm{H}, \mathrm{H}-4)$, and $3.879\left(\mathrm{~s}, 3 \mathrm{H}, \mathrm{CO}_{2} \mathrm{Me}\right)$; galactopyranose unit: $\delta 3.474\left[\mathrm{dd}, 0.7 \mathrm{H}, J_{1.2} 7.9, J_{2,3} 9.6 \mathrm{~Hz}, \mathrm{H}-2(\beta\right.$ anomer)], 4.555 (d, $0.7 \mathrm{~Hz}, J_{1.2} 7.9 \mathrm{~Hz}, \mathrm{H}-1 \beta$ ), and $5.231\left(\mathrm{~d}, 0.3 \mathrm{H}, J_{1.2} 3.6 \mathrm{~Hz}, \mathrm{H}-1 \alpha\right.$ ). The m.s. data of per- $O$-trimethylsilylated 13 (13a) are given in Table III.

Anal. Calc. for $\mathrm{C}_{18} \mathrm{H}_{31} \mathrm{NO}_{14} \cdot \mathrm{H}_{2} \mathrm{O}: \mathrm{C}, 42.94 ; \mathrm{H}, 6.61 ; \mathrm{N}, 2.78 ; \mathrm{O}, 47.67$. Found: $\mathrm{C}, 42.77 ; \mathrm{H}, 6.32 ; \mathrm{N}, 2.82 ; \mathrm{O}, 47.56$.

6-O-(Potassium 5-acetamido-3,5-dideoxy- $x$-D-glycero-D-galacto-2-nonulopyranosylonate)-D-galactose (14). - A solution of $13(57 \mathrm{mg}, 0.1 \mathrm{i} \mathrm{mmol})$ in $0.02 \mathrm{M}$ potassium hydroxide $\left(6.3 \mathrm{~mL}\right.$ ) was kept at $5^{\circ}$ until t.l.c. (solvents $C$ and $D$ ) showed that the reaction was complete $(17 \mathrm{~h})$. The mixture was concentratcd by lyophilisation and freed from alkali by elution from a column $(35 \times 2 \mathrm{~cm})$ of Bio-Gel P-2 $(200-400$ mesh) with water. The product was further purified on a column $(66 \times 2.5 \mathrm{~cm})$ of Dowex 50W-X8 (200-400 mesh, $\mathrm{K}^{+}$form) resin by elution with water, and lyophilised, to give amorphous $14(52 \mathrm{mg}, 87 \%)$. The product was homogeneous in t.l.c. (solvents $C$ and $D$ ), and had $[\alpha]_{\mathrm{D}}^{25}+16.7^{\circ}(c 0.35$, water); Neu5Ac/galactose ratio of 1.00:0.99. Methylation analysis ${ }^{33}$ of borodeuteride-reduced 14 afforded 6-O-acetyl-1,2,3,4,5penta- $O$-methyl-hexitol-1- $d$ as the neutral, partially methylated alditol acetate. ${ }^{1} \mathrm{H}$-N.m.r. data of $14\left(360 \mathrm{MHz}, \mathrm{D}_{2} \mathrm{O}\right)$ : Neu5Ac unit: $\delta$ 1.685, 1.693 [2dd, $1 \mathrm{H}$, $J_{3 a x, 3 e q}-12.2, J_{3 a x, 4} 12.2 \mathrm{~Hz}, \mathrm{H}-3 a x$ ( $\alpha$ and $\beta$ anomer of galactopyranose)], 2.033 (s, $3 \mathrm{H}, \mathrm{NAC}$ ), 2.721 (dd, $1 \mathrm{H}, J_{3 e x, 3 e q}-12.2, J_{3 e q, 4} 4.5 \mathrm{~Hz}, \mathrm{H}-3 e q$ ), and 3.575 (dd, $1 \mathrm{H}, J_{6,7} 1.5, J_{7,8} 8.6 \mathrm{~Hz}, \mathrm{H}-7$ ); galactopyranose unit: $\delta 3.469$ [dd, $0.7 \mathrm{H}, J_{1,2} 7.9$, 
$J_{2,3} 9.9 \mathrm{~Hz}, \mathrm{H}-2(\beta$ anomer $\left.)\right], 4.566\left(\mathrm{~d}, 0.7 \mathrm{H}, J_{1,2} 7.9 \mathrm{~Hz}, \mathrm{H}-1 \beta\right)$, and $5.237(\mathrm{~d}, 0.3 \mathrm{H}$, $\left.J_{1,2} 3.7 \mathrm{~Hz}, \mathrm{H}-1 \propto\right)$.

Anal. Calc. for $\mathrm{C}_{17} \mathrm{H}_{28} \mathrm{NO}_{14} \mathrm{~K}-\mathrm{H}_{2} \mathrm{O}: \mathrm{C}, 38.71 ; \mathrm{H}, 5.73 ; \mathrm{N}, 2.66$. Found: C, $38.53 ; \mathrm{H}, 5.74 ; \mathrm{N}, 2.66$.

\section{ACKNOWLEDGMENTS}

We thank Professor J. Montreuil and Dr. G. Strecker (Laboratoire de Chimie Biologique, Universite de Lille, France) for providing the urine of a sialuria patient, Mr. C. Versluis (Laboratory of Analytical Chemistry, State University of Utrecht, The Netherlands) for recording the mass spectra, Drs. L. Dorland, H. van Halbeek, and R. H. A. M. Janssen, and Mr. A. V. E. George for recording the n.m.r. spectra, Dr. C. M. Deyl for conducting the enzymic hydrolyses, and Drs. J. P. Kamerling and W. A. R. van Heeswijk for helpful discussions. This investigation was supported by the Netherlands Foundation for Chemical Research (SON) with financial aid from the Netherlands Organization for the Advancement of Pure Research (ZWO).

\section{REFERENCES}

1 R. SChauer, Angew. Chem., 85 (1973) 128-140.

2 A. Rosenberg and C.-L. Schengrund, Biological Roles of Sialic Acid, Plenum Publishing Corporation, New York, 1976.

3 J. MoNtreuil, Adv. Carbohydr. Chem. Biochem., 37 (1980) 157-223.

4 B. A. MACHER AND C. C. SWeEleY, Methods En=ymal., 50 (1978) 236-251.

5 R. W. Jeanloz and A. Closse, Fed. Proc., 22 (1963) 538.

G R. G. SpIro, Adv. Protein Chem., 27 (1973) 349-457.

7 K. IVATANABE AND S. HaKomoRI, Biochemistry, 18 (1979) 5502-5504.

8 T. Mizuochi, K. Yamashita, K. Fujikawa, K. Tmant, and A. Kogata, J. Biol. Chem., 255 (1980) 3526-3531.

9 P. Lutz, W. Lochinger, ANd G. Taigel, Chem. Ber., 101 (1968) 1089-1094.

10 R. K. YU AND R. W. LEDEEN, J. Biol. Chem., 244 (1969) 1306-1313.

11 A. Ya. Khorlin, I. M. Privalova, AND I. B. BYStrova, Carbohydr. Res., 19 (1971) 272-275.

12 F. M. UNGer, D. STIX, P.W. TAYLOR, AND G. SChULZ, in R. SChaUeret al. (Eds.), Glycoconjugates, Georg Thieme, Stuttgart, 1979, pp. 124-125.

13 R. Brossmer, H. Friebolin, G. Keilich, B. Löser, and M. Supp, Hoppe-Seyler's Z. Physiol. Chem., 359 (1978) 1064.

14 D. J. M. van der Vlefuger, W. A. R. van Heeswuk, and J. F. G. Vliegenthart, Carbohydr. Res., 102 (1982) 121-130.

15 R. KuHn, P. Lutz, ANd D. L. MacDonald, Chem. Ber., 99 (1966) 611-617.

16 A. StofFYN AND P. STOFFYN, J. Org. Chem., 32 (1967) 4001-4006.

17 K. Miyai and R. W. Jeanloz, Carbohydr. Res., 21 (1972) 45-55.

18 M. A. E. Shaban and R. W. Jeanloz, Carbohydr. Res., 52 (1976) 115-127.

19 M. M. Ponpipon, R. L. Bugianesi, and T. Y. Shen, Can. J. Chem., 58 (1980) 214-220.

20 H. J. Jennings and A. K. Bhattacharjee, Carbohydr. Res., 55 (1977) 105-112.

21 A. K. Bhattacharjee, H. J. Jennigi, C. P. Kenny, A. Martin, and I. C. P. Smith, Can. $J$. Biochem., 54 (1976) 1-8.

22 L. W. IAques, S. GLANT, AND W. WeltNeR, JR., Carbohydr. Res., 80 (1980) 207-211.

23 J. Haverkamp, H. van Halbeek, L. Dorland, J. F. G. Vlfegenthart, R. PFem, aind R. Schauer, Eur. J. Biochem., 104 (1982) 1114-1119.

24 J. F. G. Vliegenthart, H. van Halbeek, and L. Dorland, Pute Appl. Chem., 53 (1981) 45-77.

25 N. K. KochetKov, O. S. Chizhov, AND N. V. Molodtsov, Tetrahedron, 24 (1968) 5587-5593.

26 G. WUlfF, W. KRÜGer, AND G. Röhle, Chem. Ber., 104 (1971) 1387-1399.

27 J. Montreuil, G. Biserte, G. STRECKer, G. SPIK, G. Fontaine, AND J.-P. FARRIAux, Clin. Chim. Acta, 21 (1968) 61-69. 
28 J. P. Kamerling, J. F. G. Vliegenthart, J. Vink, and J. J. DE RIDder, Tetrahedron, 27 (1971) $4275-4288$.

29 J. R. Clamp, T. Bhatt, and R. E. Chambers, Methods Biochem. Anal, 19 (1971) 229-344.

30 J. P. Kamering, G. J. Gerwig, J. F. G. Vliegenthart, and J. R. Clamp, Biochem. J., 151 (1975) $491-495$.

31 L. WARRen, J. Biol. Chem., 234 (1959) 1971-1975.

32 A. LIPTÁk, I. JoDÁl, AND P. NáNásI, Carbohydr. Res., 44 (1975) 1-11.

33 P.-E. Jansson, L. Kenne, H. Liedgren, B. Lindberg, and J. Lönngren, Chem. Commun. Univ. Stockholm, No. 8, 1976.

34 J. Haverkamp, R. Schauer, M. Wember, J. P. Kamerling, and J. F. G. Vliegenthart, HoppeSeyler's Z. Physiol. Chem., 356 (1975) 1575-1583.

35 M. F. CZARniecki AND E. R. Thornton, J. Am. Chem. Soc., 99 (1977) 8273-8279.

36 V. ESCHENFEIDER AND R. BROSSMER, Tetrahedron Lett., (1975) 3069-3072.

37 W. Voelter, E. Breitmlaier, E. B. Rathbone, AND A. M. Stephen, Tetrahedron, 29 (1973) 38453848.

38 P. E. Pfeffer, K. M. Valentine, and F. W. Parrish, J. Am. Chem. Sac., 101 (1979) 1265-1274.

39 F. WEHRLI AND T. WIRTHLIN, Interpretation of Carbon-13 NMR Spectra, Heyden, London, 1978.

40 J. B. Stothers, Carbon-13 NMR Spectroscopy, Academic Press, New York, 1972.

41 G. C. LEVY AND G. L. NELSON, Carbon-13 Nuclear Magnetic Resonance for Orgunic Chemists, Wiley-Interscience, New York, 1972. 